\title{
The Effect of Project-Based Learning on First-Year Undergraduate Students in English for Specific Purposes (ESP) Courses
}

\author{
Aziza Kavlu ${ }^{1}$ \\ ${ }^{1}$ Faculty of Education, ELT (English Language Teaching) Department, Tishk International University, formerly \\ known as Ishik University Kurdistan Region, Erbil, Iraq
}

Correspondence: Aziza Kavlu, Faculty of Education, English Language Teaching Department, Tishk International University, 100 meter Road, Qazi Muhammad, Erbil, Iraq. E-mail: aziza.kavlu@tiu.edu.iq

Received: February 5, 2020

Accepted: June 7, $2020 \quad$ Online Published: June 26, 2020

doi:10.5539/ijel.v10n4p227

URL: https://doi.org/10.5539/ijel.v10n4p227

\begin{abstract}
Project-Based Learning is an approach that is significantly different from the conventional English Language Teaching method. PBL has been advocated as an effective instruction that promotes the simultaneous acquisition of language, content, and 21st-century skills to EFL (English as a foreign language) and ESL context. In this study researcher's attempt is to integrate PBL (Project-Based Learning) approach, which incorporates authentic, learning by doing, problem-solving, critical thinking and team working skills with ESP (English for specific purposes) courses. The study aimed to investigate whether the PBL projects assist EFL learners in acquiring department related literature and information in the English language and the effect of project work on learners' ESP course academic achievement. The study was conducted at Tishk International University, formerly known as Ishik University, in Iraq-Kurdistan Region with 2 Engineering (Architectural and Civil engineering) and Business and Management departments' students. A mixed-method approach was designed to make the authentic interpretation of gained results. Quantitative and Qualitative instruments were utilized to probe the effect of PBL in the ESP course of undergraduate Iraqi EFL learners. The findings of this study reveal that PBL had a significant positive effect on acquiring department-related vocabulary and information in English as well as learners' ESP course academic achievement showed statistically significant increment.
\end{abstract}

Keywords: English language learning, EFL (English as a Foreign Language) learners, English for Specific Purposes (ESP), Project-Based Learning (PBL)

\section{Introduction}

To keep up and follow a rapidly developing and changing technologic and globalized world step by step and not to fall behind, the importance of the English Language is indisputable. It is an international Language (McKay, 2002; Pennycook, 2017), Language of Science (Ammon, 2001; Pennycook, 2017), Language of the Internet (Crystal, 2012; Korpela, 2003; Zazulak, 2015) and Technology (Björkman, 2013; Kirkpatrick \& Sussex, 2012; Rehm \& Uszkoreit, 2012). Therefore, for all level learners and especially for Undergraduate students having a good command of English facilitate the way to success; and assist the academic achievement process.

On the other hand, solely English language skills are not sufficient for undergraduate students to be able to cope with challenging 21 st-century demands, professional competencies and diverse abilities become a necessity. To address the needs of the learners and to gear towards skills identified in The Future Work Skills Report 2020 (Tyagi \& Kannan, 2013)—“sense-making, social intelligence, novel, and adaptive thinking, cross-cultural competency, computational thinking, new-media literacy, transdisciplinarity, design mindset, virtual collaboration", Project-Based Learning is one of the learning approaches that enables learners to acquire some above mentioned progressing era abilities.

As the researcher is an English Language lecturer in one of the private Universities in Iraq, she has observed through whole her teaching experience in this region, students long for being able to speak English fluently, comprehend English written material and speak comfortably, and have a good or in other words the perfect level of English. At this point, the question 'Why?' arises - because as in all Gulf countries in Iraq also having good commands of English accepted prestigious. Employers give preference to the applicant with a better English level. Mostly in all private universities and public universities (in departments with high entrance scores - such as Faculty of Medicine, Faculty of Dentistry, Engineering and Science departments), and especially in 
private-high, secondary and primary schools, English is a Medium of Instruction. On the other hand, although English is the most desirable language to be acquired, still at post-school at the tertiary level - more particularly First Grade Level Students neither can speak nor understand the English written material, except a few private schools, graduated students. Another big handicap faced with University students is the Education and examination system, even mandatory exams, based on rote learning, which blunt learners' creativity, critical thinking, analyzing, synthesizing, making inferences skills and hinders the improvement of students' distinctive ideas. Characteristics described above are usually encountered university first-grade students' profile. However, the 21st-century high-competitive, original idea hunting and multi-skills or talented employees seeking environments and the significance of such factors in students' post-graduate life cannot be neglected and ignored by educators. Real-life and employment area requirements boost educators to be active followers of innovation, latest, and potential developments. Methodically rearrange, recheck, and redesign the education system concerning 21 st rapidly-developing age standards. It's going without saying actualizing necessary amendments are not sufficient. The education system with applied methods and approaches should be assessed to identify the strengths and weaknesses of the system and to make the step towards getting better and synchronizing with the real-life setting. Thus, in this study researcher's attempt is integration of the PBL (Project-Based Learning) approach, which incorporates authentic, learning by doing, problem-solving, critical thinking and team working skills with ESP (English for specific purposes) courses. This assemblage one of the ways that activate learners, put them in the center of the learning process and assist educators in taking out learners from a close rote memorization circuit.

\section{Theoretical Background}

\subsection{Project-Based Learning}

In this article, the researcher is investigating the effect of PBL on the ESP platform. Hence in the literature review section, she tried to provide brief to the point and clear view of PBL. We should recognize that it can be hard to extract all the benefits of PBL and its integration into the EFL context in the article format.

When the researcher scrutinizes literature, it can be argued that PBL has the potential to generate more memorable, more powerful, real-life connected and on purpose learning experience for learners. The previously mentioned characteristics of PBL were practically tested and proved by Boss and Krauss (2014) in several school networks that are good examples of PBL implementation. Project-Based Learning is an educational system where learners face with meaningful real-world problems and cases, learners determined how to deal with them and then collaboratively try to find problems' solutions (Barell, 2006; Bender, 2012), meanwhile students pass through natural English Language practice and department related English language terminology acquisition.

Project-Based Learning based on constructivist, social-constructivist and other contemporary instructional theories' principals (Agustina, 2009; Bruner \& Anglin, 1973; Gülbahar \& Tinmaz, 2006; Helle, Tynjälä, \& Olkinuora, 2006; Sidman-Taveau, 2005; Sidman-Taveau \& Milner-Bolotin, 2001; Simpson, 2011; Welsh, 2006). Concerning constructivist schools of thought, knowledge is not only transmitted or taught, but leaners themselves should also be active in the process of understanding and knowledge acquisition (Benson, 2013; Kavlu, 2015; Yam \& Rossini, 2010). The learning process actualizes when learners able to link newly acquired information with their background knowledge, as new ideas and concepts arise learners restructure their existing knowledge (Bransford, Brown, \& Cocking, 1999; Mascolo, 2009; Reigeluth, 1999). This constructivist aspect of Project-Based Learning enables learners to shift from traditional Iraqi teacher-centered, stereotyped and spoon-fed teaching style to dynamic learning atmosphere, where they learn by doing (conducting interviews and surveys, field trips, investigations, data collecting, analyzing, make inferences and present them).

Fried-Booth (1986) was one of the forerunners who introduced the term 'project' to the EFL context. Doing PBL's projects is an inherent integration and synchronization of English Language to real-life settings. Gathering data and information through reading, listening, watching, interviewing, collaborative discussion about the assigned topic, the deliberation, and analysis of the obtained data in the target language within the group, writing reports and the texts of posters or presentations, these all are the natural integration of target language with academic and real-life skills. Hedge (2000) asserted that projects are wide-broad tasks that enable learners to reunite language skills with multifarious authentic activities.

Several empirical studies reported the effectiveness of Project-Based Learning in the EFL context.

Bas (2011), in his study with 60 ninth Grade urban area (Turkey) High School students, investigated the effects of Project-Based Learning on learners' academic achievement and their attitudes towards English lessons. Bas experimental study's findings were also supported by other studies carried out both in Turkey and other countries with students in different grades and field of education (Baş \& Beyhan, 2010; Meyer, Turner, \& Spencer, 1997; 
Sylvester, 2007; Yalcin, Turgut, \& Buyukkasap, 2009). The findings of studies revealed that PBL had a positive contribution to the development of learners' academic achievement levels (enhance students' sense of responsibility, equipped them with motivation to learn). Furthermore, the experimental group (PBL implemented group) performed significantly better and had more positive attitudes towards English lessons.

Kavlu (2016), a long-term doctoral thesis study in one of the private universities in the Kurdistan Region of Iraq examined the effect of Project-Based Learning on EFL undergraduate students' reading skills. The study quantitatively (statistically) and qualitatively proved the significant increase and enhancement of freshman students' English Language Reading skills, accordingly, their English Language comprehension ability improved.

Sadeghi, Biniaz, and Soleimani (2016) research with 36 Iranian male students at Language Institute showed that the learners who were educated by Project-Based Learning outperformed in comparison and contrast paragraph writing skills in English than the students who were educated by instruction based on students' textbook.

The doctoral thesis of Simpson (2011) is an empirical study that provided an in-depth examination of the effects of PBL integration in English language Tourism classes of third-year students of Thai University. These research study's findings indicated that there were highly statistically significant differences between pre and post-tests of speaking skills regardless of participants' level (low, medium and high achievers). In other words, this means that Project-Based Learning had a significant positive influence on learners' English language speaking skills.

Put in a nutshell, through the researches which tried to investigate the effects of PBL in EFL context it can be observed that Project-Based Learning maintains its positive effects on the active development of learners' language skills, intellectual improvement in learning, academic achievement and positive attitudes towards learning process itself as well as in science, math and other branches of education.

\subsection{Project-Based Learning in ESP Context}

PBL and ESP blossoming in the EFL context almost commenced in the same decades. The end of the Second World War (Huthchinson \& Water, 1996), the 20th-century industrial revolution and the United States' post-war economic power enhanced the importance of English as an international language. Moreover, in the 1970s, The Oil Crisis caused the flow of Western knowledge and money to oil-rich countries. English was the language of this transmission (Gatehouse, 2001).

When LSP-Language for Specific Purpose applies to the English Language it becomes ESP-English for Specific Purposes. However, what is appropriate and specific in one part of the world it may not be elsewhere. Therefore, it is not easy to generate a worldwide accepted definition of ESP. Concerning Jarvis's (2004) definition, ESP comprises study skills with language competencies to equip non-native speakers for academic thriving.

In ESP, the acquisition of English Language actualizes through a domain that is already known and relevant to the students (Hans \& Hans, 2015). When considered from this point of view, PBL and ESP remarkably can assist and support one another, because as constructivism one of the theoretical basis of PBL, the learners should activate and link their existing knowledge with the new information to procure knowledge formation. This means that PBL integration to ESP courses enables learners to apply their knowledge and abilities and the English they know to learn not only more English and major-related English but also to enhance their studies relevant knowledge in a collaborative, investigative and authentic way.

Another contribution of PBL to ESP course, it provides learners with the opportunity to demonstrate mastery of their study's field by generating and presenting the projects which are research-based and carried out consonantly with learners' interests what makes possible for learners to work within similar parameters like real researchers (Klein et al., 2009) as well as have natural acquisition and practice of department-related English. These characteristics play a substantial role to gradually adapt students with rote - type education system backgrounds to inquiry-based academic life, in-depth and analytical thinking and make students competent in the 21st high-competitive century's demands.

According to Gatehouse (2001), ESP meets the specific needs of the learners. The undergraduate language learners Specific needs are English language skills to perpetuate academic life - be able to understand and write in English at an academic level, to express themselves and communicate in English and use English to expertise in their departments (fields). Considered from this aspect, PBL concerning Jiménez Raya (1994) cites in Díaz Ramírez (2014) definition, project work is an improvement of experience-based and centered on learners and their environments, it is one of instruction that facilitates and accelerates ESP implementation. Furthermore, working on in-depth projects in ESP courses gives learners the opportunity to get a wide range of information on 
the topic under investigation, "exportable knowledge" - what means learners can transmit explored information to real knowledge, transfer or "export" it into dialogue with others (Klein et al., 2009), and simultaneously enhance and practice their English language skills. In addition to these generally, students learn more than they present in their final product-presentations.

In ESP courses, objectives often are to improve learners' language required for academic or occupational settings and focuses more on language in context than on grammar and language structure (Hans \& Hans, 2015). The focal point of ESP is that English is not taught as a separate discipline from students' real-world and major's needs, instead, ESP is a combination of subject matter and English language teaching. At this point, we observe the intersection of ESP and PBL in terms of Content-Based Instruction (CBI), as the researcher generated and showed below in Figure 1. Empirical researches of Kavaliauskiene (2004) and Ngan (2011) aver that CBI enables ESP course learners to practice English language skills and acquire subjects knowledge simultaneously, and Project-Based Learning is the fructiferous platform for integration of content learning and English language skills in authentic settings in ESP course.

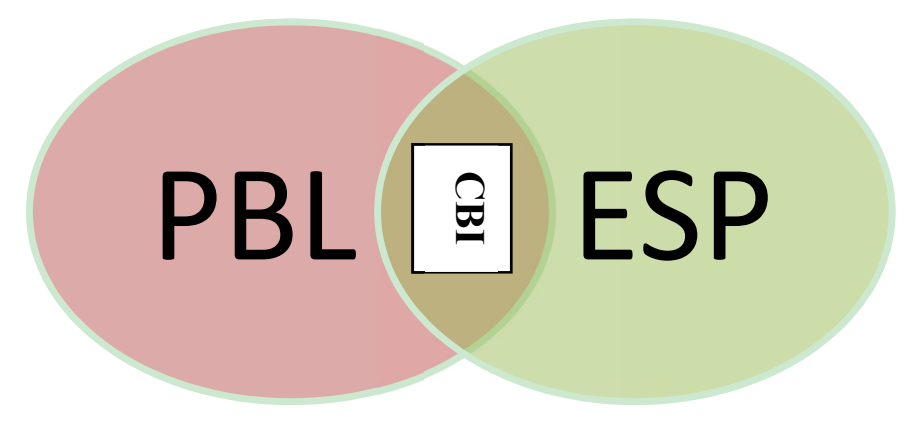

Figure 1. The intersection of PBL and ESP (Source: Generated by Researcher)

Furthermore, some implementations of integrating learners' pen and pencil based (Sheppard \& Stoller, 1995; Stoller, 1997) and computer-assisted projects (Mamakou, 2009; Sidman-Taveau, 2005) into ESP courses have already been published.

\section{Purpose of the Study}

The study aims to seek the effect of PBL-Project-Based Learning in ESP courses of First-Year undergraduate EFL learners of Tishk International University, formerly known as Ishik University.

\subsection{Research Questions}

The present study attempts to investigate the answers to the following questions:

1) What are students' English Language backgrounds in Architecture Engineering, Civil Engineering, and Business and Management Department of Tishk International University Sulaimaniyah, formerly known as Ishik University?

2) What is the contribution of projects to students' field related English?

3) What are student's opinions about how Project-Based Learning enhances their English language skills?

\subsection{Research Hypotheses}

The current study examined and verified the validity of the following hypothesis.

Hypothesis 1-The implementation of PBL in ESP courses has a statistically significant impact on EFL learners' ESP course academic achievement.

\section{Research Methodology}

\subsection{Research Design}

A mixed-method approach was designed to enable the researcher to make the authentic interpretation of gained results. Quantitative and Qualitative instruments were utilized to probe the effect of PBL in the ESP course of undergraduate Iraqi EFL learners. This study's methodology is based on some researches which were applied without a control group such as; 
Simpson's (2011) doctoral dissertation "Integrating Project-Based Learning in an English Language Tourism classroom in a Thai University" is an empirical study with third-year English major students in English for Tourism Course. This study provided an in-depth examination of PBL integration into the EFL context and quantitatively and qualitatively proved the significant effect of PBL not only on students' English Language skills but also PBL assists students in learning skills and strategies improvement. TOEFL—Reading IBT, Listening, Speaking and Writing were quantitative instruments, where derived data proved the statistically significant effect of PBL.

Students' surveys, diaries, open-ended questionnaires, field notes and work in progress discussion were employed as qualitative research instruments which revealed that the PBL approach fostered learners to gradually enhance their confidence in the use of English language skills and give learners opportunity to discover new knowledge through logical thinking and reasoning.

Rousová (2008), diploma work is a multi-layered long-term Project-Based Learning project with a wide range of activities for the intermediate level learners shows that PBL comprises all the contributions of conventional EFL techniques together with contemporary progressive teaching approaches and ideas.

Furthermore, there are numbers of small and large scale researches that proved the positive and statistically significant effects of Project-Based Learning in EFL/ESL/ESP context by carrying out studies with control and experimental groups (Baş, 2011; Beckett, 1999; Chu, Tse, Loh, \& Chow, 2011; Kavlu, 2016; Ke, 2010; Nassir, 2014). Therefore, in this study Researcher's purpose was to apply Project-Based Learning to all groups and do not leave any group without treatment-PBL implementation. It's going without saying the traditional teaching method is already the system that students get used to and it would pose no problems to continue the traditional education system with control group/groups. However, the researcher did not set sight on obtaining the desired result and proved determined hypothesis under any circumstances, on the contrary, the researcher's intent as an educator is to introduce Project-Based Learning method, which success, authenticity, and 21st-century compatibility have been proven, to all departments' students and allow them to be in and enjoy the positive and collaborative environment of PBL. As students get ESP courses only in the First Year of University and research was carried through 2 semesters - whole academic year to get more reliable results, what means that the control group would not have a chance pass through PBL experience.

To reveal students' English background and evaluate the effect of PBL on students' English language skills, the researcher employed a quantitative research instrument - questionnaire. Quantitative data was collected mainly through questionnaires. In the role of teacher-researcher, the Researcher was directly involved in all aspects of research; planning, designing, implementation, and evaluation process. This may have caused some subjectivity, to eliminate the researcher bias, various methods of data collection were employed. Additionally, the bias can be encountered during data interpretation; therefore, the researcher attempted to minimize the bias by employing and taking into account the independent observation and evaluation of the Researcher's lectures by the Head of related departments.

\subsection{Participants}

The present study was carried out in one of the private universities in Sulaimania-KRG (Kurdistan Regional Government) Iraq. The participants of this study consisted of First-Year Students of the Architectural Engineering Department, Civil Engineering Department, and the Business and Management Department.

Table 1. Distribution of students in the departments in terms of number, gender, and nationality

\begin{tabular}{llllll}
\hline Name of Departments & Gender & \multicolumn{3}{l}{ Nationality } \\
\cline { 2 - 5 } & Female & Male & Kurdish & Arab & Total \\
\hline Architectural Engineering & 15 & 6 & 21 & & 21 \\
Civil Engineering & 3 & 13 & 16 & & 16 \\
Business and Management & 11 & 13 & 21 & 3 & 24 \\
Total & 29 & 32 & & & 61 \\
\hline
\end{tabular}

Books that were used during PBL implementation-Business and Management Department Course Book was-Market Leader-Business English Course Book (Cotton, Falvey, \& Kent, 2012). Architecture and Civil Engineering Course Book was-Cambridge English for Engineering-Cambridge professional English (Ibbotson, 2008). The content of the projects was determined in parallel with the topics in the book. 
Table 2. Type of projects and requirements

\begin{tabular}{ll}
\hline Type of Projects & Requirements \\
\hline $\mathbf{1}^{\text {st }}$ Project & $\checkmark \quad$ Their Careers' Move, Works, Plan \\
3 Famous Architects in Iraq / KRG and the world & $\checkmark \quad$ Give examples of their outstanding works which made them \\
3 Famous Civil Engineers in Iraq / KRG and the world & famous \\
3 Famous Business Leaders (business lady/men) in Iraq / KRG & $\checkmark \quad$ People Comments and Opinions about them \\
and the world & $\checkmark \quad$ Conduct Questionnaire at least to 15 people to find out the ways, \\
& strategies, and skills how to be a successful architect/civil \\
& engineer/business leader \\
$\mathbf{2}^{\text {nd }}$ Project & $\checkmark \quad$ Evaluate, analyze and present your conclusions \\
Materials used in Constructions of Suleymania & Which types of materials are used generally in Building Constructions \\
(Civil Engineering Department's project) & (or any other construction that you decided to investigate it) in \\
& Suleymania. \\
& In which parts of constructions these materials are used, and Why? \\
& Interview with 5 contractors or apply a questionnaire to them to prove \\
$\mathbf{3}^{\text {rd Project }}$ & your information effectively. \\
The new attraction in your area/country (Iraq, Kurdistan, & Present 2 research articles that will prove your information \\
Sulaimania) & scientifically. \\
An international competition will encourage great ideas for a & What are the strong points of your great idea? \\
new visitor attraction & What kind of experience will your attraction offer visitors? \\
(Business and Management Department's project) & How will it make money for the local community? \\
\hline & What are your plans for marketing and promoting the attraction? \\
\hline
\end{tabular}

\subsection{Instruments and Data Collection}

The following instruments were employed to collect data in this study:

\subsection{Quantitative Instrument and Qualitative Instrument}

The purpose of this study was to examine the effect of Project-Based Learning on First-Year Undergraduate EFL students' ESP course achievement. Quantitative data collection was utilized to assess learners' achievement in English language skills in ESP courses across the groups (departments) at the beginning and the end of the study (pre and post-tests). Statistical Package for Social Sciences (SPSS-22) was utilized to collect data and Paired Sample T-tests were run to analyze the data.

The survey was arranged and carried out to reveal students' English Language learning background, students' previous (pre-university) project experiences, the contribution of projects to students' field related English (ESP), and students' opinions about PBL's effect on their English language skills and other academic skills.

A questionnaire was composed with 8 Yes/No questions, students rate the degree of agreement on each statement with a five-point Likert Scale ration criterion ranging from 1 (strongly disagree) to 5 (strongly agree). Codes 4 and 5 (agree and strongly agree) and codes 1 and 2 (disagree and strongly disagree) were tallied together. These parts of the questionnaire were analyzed by SPSS-22. The questionnaire items were first written in English, and then students were provided with translations in their native language to prevent language difficulty and to better comprehension, and in the process of application, written instructions were verbally explained.

To get more in-depth information, a qualitative instrument semi-structured interview was conducted. The semi-structured interview was used not to limit and to allow respondents (interviewee) her/him to discuss issues that the researcher may not consider in the questionnaire, and for triangulation with the result of the questionnaire.

\section{Findings and Discussions}

The length of this study was one semester for the Architectural Department and 2 semesters for Civil Engineering and Business and Management departments. The gathered data was sufficient to answer the research questions.

Based on the answers delineated from the questionnaire, 100\% (all students) used Sunrise book in the High School as an English Course Book. However Sofi-Karim (2015), in his Master thesis analyzed the book and remarked that Sunrise fails to meet the need of Kurdish English learners, fails to fulfill objectives to raise students' communicative competence, fails to address the global topics, inappropriate culturally and 
pedagogically for students, and indicated numbers of inadequacies of this coursebook.

$15 \%$ percent of students did traditional style projects (copy and pasting), and $85 \%$ of students did not do any type of project in English class in High school. Only 1 student (1.6\%, from a private school) did the project that required research and $98 \%$ of students never did any research-based projects. This shows that English lessons in the schools are not the lessons that required researches, it is the lesson where course book information memorized and students asked to pass the exams by rote memorization.

Before doing the first project $67.2 \%$ of students did not have any information about assigned project's topic, $89 \%$ of students did not know any famous person (architect, civil engineer, business leader) related to their department, $11 \%$ of students got information about assigned people not because of their research, but because they met this information somehow in everyday life.

$97 \%$ of students stated that the project making process made them acquire department related knowledge.

Table 3. Table PBL's effect on students' English language skills

\begin{tabular}{|c|c|c|c|c|c|}
\hline & $\begin{array}{l}\text { Strongly } \\
\text { Disagree }\end{array}$ & Disagree & Not sure & Agree & $\begin{array}{l}\text { Strongly } \\
\text { Agree }\end{array}$ \\
\hline To find required information for the project I read a lot of texts & $3 \%$ & $1.6 \%$ & $3 \%$ & $31 \%$ & $61 \%$ \\
\hline $\begin{array}{l}\text { PBL (Project-Based Learning)' projects improve my English language } \\
\text { reading skills because to accomplish the projects I read more than once } \\
\text { time }\end{array}$ & $1.6 \%$ & & $8 \%$ & $34 \%$ & $56 \%$ \\
\hline $\begin{array}{l}\text { I looked up the meaning of the words that help me understand the } \\
\text { reading text better }\end{array}$ & $3 \%$ & $3 \%$ & $7 \%$ & $26 \%$ & $66 \%$ \\
\hline I try to write the text of presentations correctly & & & & $43 \%$ & $57 \%$ \\
\hline I write a summary to the part that I have to explain & & $14 \%$ & $11 \%$ & $46 \%$ & $29 \%$ \\
\hline I learn new vocabulary related to my department & & & $3 \%$ & $37 \%$ & $59 \%$ \\
\hline While listening to my friends' presentations, I obtain new information & $3 \%$ & $8 \%$ & $11 \%$ & $49 \%$ & $29 \%$ \\
\hline $\begin{array}{l}\text { I repeat my part several times to my group members before the real } \\
\text { presentation }\end{array}$ & & $5 \%$ & $3 \%$ & $62 \%$ & $30 \%$ \\
\hline
\end{tabular}

In reference to Table 3, 92\% (Agree 31\%+ Strongly Agree 61\%) of students do a lot of reading to find out the necessary information in the process of doing the project. Learners naturally practice and apply skimming skills (read or look to get a general idea of the contents) and scanning skills (looking at a text to search and find some particular information), do plenty of department-related as well as English language reading. However, 4.6\% disagree and $3 \%$ are not sure about this issue. $90 \%$ of students agreed that reading more than once when doing project improve their English Language reading skills, while 8\% is not sure and 1.6\% disagreed. Doing PBL's projects also assists learner's department related English language vocabulary formation, $92 \%(66 \%+26 \%)$ look up the dictionary to a better comprehension of the reading material, while $7 \%$ is not sure and $6 \%$ of students do not look up the dictionary. Besides, 57\%-Strongly agree and 43\%-Agree-almost all students show great care to write their presentation's texts correctly. This enables learners to practice mistake-free writing of words and build up the grammatically correct structure. $75 \%$ of students prepare writing notes for their oral presentation what means students practice summarizing skills to be able to prepare their notes, while $25 \%$ of them do not feel the need to short notes. Almost all students $96 \%$ acquire department-related new vocabulary during the project making process. $88 \%$ of students listen to their peers and obtains new information from these presentations, while $11 \%$ of students state that they do not get new information from their course mates' project presentations. Almost all students $92 \%$ rehearse their presenting part before the actual presentation, and this enhances students' public speaking skills.

Table 4. Students' perception of the project work

\begin{tabular}{llllll}
\hline & Strongly Disagree & Disagree & Not sure & Agree & Strongly Agree \\
\hline Doing projects is interesting & $3 \%$ & $7 \%$ & $12 \%$ & $32 \%$ & $46 \%$ \\
Doing projects is hard work & $7 \%$ & $7 \%$ & $22 \%$ & $32 \%$ & $32 \%$ \\
\hline
\end{tabular}

In reference to Table 4, 78\% of learners find out the project work interesting meanwhile, $64 \%$ of students believed that doing a project is hard work. However, $10 \%$ of students think that project work is not interesting. Besides that, for $22 \%$ of students project work is not hard, but it is not easy either, and only $14 \%$ of learners 
don't think that doing a project is hard. It means that doing projects attracted learners' interests, but it was not the style of assignments that they were got accustomed to (filling the gaps, memorizing, and copy-pasting). It was also manifested and understood from the interviews with members of groups and students' statements during project completion guidance process with the lecturer (researcher), learners previously had not done any research-based project especially in non-math courses such an English language class, they did not know research techniques - how to collect data, how to interpret obtained information, draw conclusions and make their deduction. These inadequacies appeared to be the factors that students had difficulty in dealing with. Nonetheless, students expressed that doing projects is not easy, $78 \%$ of learners believed that doing projects stimulate their interest and raise their curiosity.

The most common responses to the interview and open-ended questions of collected data were summarized below: What have you learned by doing PBL projects?

We should never give up and be able to take the work we started up to the end. I have learned many new different words related to my department.

I have learned how to work with the group and help each other and I have to work hard to achieve the goals I have set.

I have learned how I can get information from the internet, how to filter and evaluate it and how we should behave while presenting our projects (how to behave, how to speak, what to wear).

I have learned the importance of teamwork and how properly state your personal opinion. The English language is not only Present Simple and Present Continuous-learning language it is not just about learning Grammar.

Although doing projects were a completely new style of learning, this learning way is very exciting.

While doing projects, the information that I have learned is related to both language learning and department related knowledge.

Doing projects was a great opportunity to break down stereotyped language and general learning rules.

Doing projects was a good experience to learn how to generate unique and innovative ideas.

By summarizing learners' feedbacks, it can be said that doing PBL based projects allow students to acquire not only English Language related but also department related knowledge and vocabulary. Doing projects in the ESP course shifts learners from a conventional teaching platform to a more path-breaking learning environment where they can produce and propound more seminal works.

A quantitative method of data analysis was utilized for the evaluation of the obtained pre- and post-experimental data.

Table 5. Paired samples statistics of Architecture Engineering, Civil Engineering and Business and Management students' achievement in ESP course pre and posttests results

\begin{tabular}{lllll}
\hline & Mean & N & Std. Deviation & Std. Error Mean \\
\hline Arch. Eng. Group Pre-Test & 53.7143 & 21 & 19.53751 & 4.26343 \\
Arch. Eng. Group Post-Test & 80.2857 & 21 & 13.68263 & 2.98579 \\
Civil Eng. Group Pre-Test 1. Semester & 39.6875 & 16 & 20.98164 & 5.24541 \\
Civil Eng. Group Post-Test 1. Semester & 70.3750 & 16 & 14.57795 & 3.64449 \\
Civil Eng. Group Post-Test 2. Semester & 89.1250 & 16 & 8.10658 & 2.02665 \\
Business Group Pre-Test 1. Semester & 42.6250 & 24 & 17.63843 & 3.60043 \\
Business Group Post-Test 1. Semester & 67.0417 & 24 & 15.49608 & 3.16312 \\
Business Group Post-Test 2. Semester & 82.9583 & 24 & 10.17875 & 2.07773 \\
\hline
\end{tabular}

Based on the results delineated from Table 5 before the implementation of PBL the means of groups were as in Table 6.

Table 6. All groups pretest and posttest mean

\begin{tabular}{llll}
\hline & Architecture Eng. & Civil Eng. & Bus. \& Mang. \\
\hline Pre-test Means & 53.7143 & 39.6875 & 42.6250 \\
Post-test Means & 80.2857 & 89.1250 & 82.9583 \\
\hline
\end{tabular}


As each group was assessed statistically within itself, not with each other, therefore being worse or better than other groups at pretest was not a principal focal point. On the other hand, the Architecture Engineering Department students outperformed in pretest one of the reasons is - the majority of these students had better English Language school background.

Table 7. Paired sample t-test, pretest and post-test mean compare Architecture Engineering students' achievement

\begin{tabular}{|c|c|c|c|c|c|c|c|c|}
\hline & \multicolumn{5}{|c|}{ Paired Differences } & \multirow{3}{*}{$\mathrm{t}$} & \multirow{3}{*}{$\mathrm{df}$} & \multirow{3}{*}{$\begin{array}{l}\text { Sig. } \\
\text { (2-tailed) }\end{array}$} \\
\hline & \multirow[t]{2}{*}{ Mean } & \multirow{2}{*}{$\begin{array}{l}\text { Std. } \\
\text { Deviation }\end{array}$} & \multirow{2}{*}{$\begin{array}{l}\text { Std. Error } \\
\text { Mean }\end{array}$} & \multicolumn{2}{|c|}{ 95\% Confidence Interval of the Difference } & & & \\
\hline & & & & Lower & Upper & & & \\
\hline Pair 1 pre-test - post-test & -26.5714 & 8.70386 & 1.89934 & -30.53 & -22.6094 & -13.990 & 20 & .000 \\
\hline
\end{tabular}

To prove whether there is a statistically significant difference between the mean scores of the pre-tests and post-tests of Groups Paired Sample t-tests were run.

Table 7 displays the computation of $\boldsymbol{t}$ - the value of the Architecture Engineering Department. Results showed that the $\boldsymbol{t}$-value with its 20 degrees of freedom (df) was .000. Since the $\boldsymbol{t}$ observed (.000), which is smaller than 0.05 the level of significance it can be inferred that the difference between pre and posttest was statistically significant. It confirmed that PBL implementation even in the short term (1- academic semester) had a positive effect on Architecture Department students' ESP course achievement. Doing PBL's projects increased mean scores from 53.71 to $80.29(80.29-53.71)=26.57$. The Paired Sample test proved the statistical significance of this uptrend.

Table 8. Paired sample t-test, pretest and post-test mean compare of Civil Engineering students' achievement

\begin{tabular}{|c|c|c|c|c|c|c|c|c|}
\hline & \multicolumn{5}{|c|}{ Paired Differences } & \multirow{3}{*}{$\mathrm{t}$} & \multirow{3}{*}{ df } & \multirow{3}{*}{$\begin{array}{l}\text { Sig. } \\
\text { (2-tailed) }\end{array}$} \\
\hline & \multirow[t]{2}{*}{ Mean } & \multirow{2}{*}{$\begin{array}{l}\text { Std. } \\
\text { Deviation }\end{array}$} & \multirow{2}{*}{$\begin{array}{l}\text { Std. Error } \\
\text { Mean }\end{array}$} & \multicolumn{2}{|c|}{$95 \%$ Confidence Interval of the Difference } & & & \\
\hline & & & & Lower & Upper & & & \\
\hline Pair 1 pretest - posttest 1 & -30.6875 & 12.68447 & 3.17112 & -37.4465 & -23.9284 & -9.677 & 15 & .000 \\
\hline Pair 2 posttest $1-$ posttest 2 & -18.75000 & 8.62168 & 2.15542 & -23.34417 & 14.15583 & -8.699 & 15 & .000 \\
\hline
\end{tabular}

As Table 8 depicts, the $\boldsymbol{t}$ - value with is 15 degrees of freedom was (-9.677) - for Pair 1 and (-8.699) - for Pair 2 , and the value of Sig. $(2$ tailed) is .000 at .05 level of significance $(p<.05)$. It means the implementation of the PBL approach has a significant effect on Civil Engineering students' ESP course achievement. In the first semester students' scores increased from 39.687 to $70.375(70.375-39.687)=30.6875$ and in the second semester from 70.375 to $89.1250(89.1250-70.375)=18.750$. The Second term achievement score growth is lower than in the first term. However, both increments are statistically significant.

Table 9. Paired sample t-test, pretest and post-test mean compare of Business and Management students' achievement

\begin{tabular}{|c|c|c|c|c|c|c|c|c|}
\hline & \multicolumn{5}{|c|}{ Paired Differences } & \multirow{3}{*}{$\mathrm{t}$} & \multirow{3}{*}{ df } & \multirow{3}{*}{$\begin{array}{l}\text { Sig. } \\
\text { (2-tailed) }\end{array}$} \\
\hline & \multirow[t]{2}{*}{ Mean } & \multirow{2}{*}{$\begin{array}{l}\text { Std. } \\
\text { Deviation }\end{array}$} & \multirow{2}{*}{$\begin{array}{l}\text { Std. Error } \\
\text { Mean }\end{array}$} & \multicolumn{2}{|c|}{$95 \%$ Confidence Interval of the Difference } & & & \\
\hline & & & & Lower & Upper & & & \\
\hline Pair 1 pretest - posttest 1 & -24.4166 & 8.30357 & 1.69496 & 27.92296 & -20.9103 & -14.405 & 23 & .000 \\
\hline Pair 2 posttest $1-$ posttest 2 & -15.9166 & 11.22852 & 2.29201 & -20.6580 & -11.1752 & -6.944 & 23 & .000 \\
\hline
\end{tabular}

In reference to Table 9, since the value of two-tailed significance is .000 and (pair $1 \mathrm{t}=-14.405$ and pair $2 \mathrm{t}=$ $-6.944)$ with 23 degrees' o freedom and it is lower than $\alpha(.05)$. Therefore, the significance of differences between pre and post-tests was statistically proved. That means Business and Management Department students gradually outperformed from pretest to the $1^{\text {st }}$ posttest and then to the $2^{\text {nd }}$ posttest.

Based on the data shown in Tables 7, 8 and 9, since the $\boldsymbol{p}$-value of two-tailed significance is .000 and it's lower than $\alpha(.05)$, the results of Paired Sample tests can be used to reject the null $\left(\mathrm{H}_{0}\right)$ hypothesis. The implementation of PBL in ESP courses has a statistically significant impact on EFL learners' ESP course academic achievement. 


\section{Conclusions}

Based on Discussion and Findings, it can be concluded that the Project-Based Learning approach can be one of the effective methods in the ESP course. The findings reveal that the majority of students come from rote memorization teaching background, did not do any projects and researches before the implementation of PBL's project in the ESP course. $92 \%$ of students did plenty of department information related as well as English Language reading. The finds also indicated that while preparing project presentation texts, almost all students practiced grammatically correct and mistake-free writing. $96 \%$ of students acquired department related to new vocabulary, and presenting projects improve students' public speaking skills. Moreover, according to students' statements doing projects enables them to experience innovative, exciting, path-breaking learning methods. Furthermore, concerning qualitative and quantitative data findings, PBL implementation significantly contributes to increasing undergraduate students' ESP course achievement. All group participants' students were provided with self, peer, and lecturer assessment rubrics, which develop the formation of the ability to provide constructive and academic feedback. PBL instruction maintains a learner-centered environment, the integration of PBL to ESP course gain students with self-learning and self-developing abilities. Besides, findings also proved the short- and long-term positive contribution of PBL to ESP course achievement. BPL implementation in the ESP course allows students to put into practice their theoretical knowledge. One of the main problems that students have, is that they face difficulties while doing teamwork in the project completion process. However, solving problems and overcoming difficulties enhance students learning capabilities and bring them new competency.

\section{Limitations}

Several limitations were also worth considering. The study was run in the Kurdistan Region of Iraq with First-Year students. It is hard to determine, whether the findings obtained from the research can be generalized fully.

Another limitation of the study is the number of students and research was applied to one private University. The study can be implemented in public universities to obtain wide-scale results. These limitations will open a new room for further study to explore the effect of PBL more comprehensively.

\section{Future Study}

The qualitative and quantitative findings of this study can also provide the basis for further researches on exploring more benefits of PBL implementation on the ESP course of undergraduate students. Research in the future can further investigate topics such as; "Extracurricular activities in Project-Based Learning and their effects on undergraduate EFL learners", "The effect of PBL on ESP course undergraduate students' pragmatic competence".

\section{Acknowledgments}

I would like to thank all students who participated in this study. Their contributions were the source of my research. I wish to thank Dr. Ahmet Demir, who gave countenance to statistical calculation.

\section{References}

Agustina, L. (2009). Improving Reading and Speaking Skills through Project-Based Learning for EFL students in the Form of Student-Made Newsmagazine. DISERTASI dan TESIS Program Pascasarjana UM.

Ammon, U. (2001). The Dominance of English as a Language of Science: Effects on Other Languages and Language Communities. De Gruyter. https://doi.org/10.1515/9783110869484

Barell, J. F. (2006). Problem-Based Learning: An Inquiry Approach. SAGE Publications.

Baş, G. (2011). Investigating the effects of project-based learning on students' academic achievement and attitudes towards English lessons. The Online Journal of New Horizons in Education, 1(4).

Baş, G., \& Beyhan, Ö. (2010). The effects of multiple intelligences supported project-based learning on students' achievement levels and attitudes towards English lessons. International Electronic Journal of Elementary Education, 2(3), 365-385.

Beckett, G. H. (1999). Project-based instruction in a Canadian secondary school's ESL classes: Goals and evaluations. The University of British Columbia.

Bender, W. N. (2012). Project-based learning: Differentiating instruction for the 21st century. Corwin Press.

Benson, P. (2013). Teaching and Researching: Autonomy in Language Learning. Taylor \& Francis. https://doi.org/10.4324/9781315833767 
Björkman, B. (2013). English as an Academic Lingua Franca: An Investigation of Form and Communicative Effectiveness. De Gruyter. https://doi.org/10.1515/9783110279542

Boss, S., \& Krauss, J. (2014). Reinventing project-based learning: Your field guide to real-world projects in the digital age. International Society for Technology in Education.

Bransford, J. D., Brown, A. L., \& Cocking, R. R. (1999). How people learn: Brain, mind, experience, and school. National Academy Press.

Bruner, J. S., \& Anglin, J. M. (1973). Beyond the Information Given: Studies in the Psychology of Knowing. W. W. Norton \& Company Incorporated.

Chu, S. K. W., Tse, S. K., Loh, E. K. Y., \& Chow, K. (2011). Collaborative inquiry project-based learning: Effects on reading ability and interests. Library \& Information Science Research, 33(3), 236-243. https://doi.org/10.1016/j.lisr.2010.09.008

Cotton, D., Falvey, D., \& Kent, S. (2012). Market Leader. Pearson Education.

Crystal, D. (2012). English as a Global Language. Cambridge University Press.

Díaz Ramírez, M. I. (2014). Developing Learner Autonomy Through Project Work in an ESP Class. How, 21(2), 54-73. https://doi.org/10.19183/how.21.2.4

Fried-Booth. (1986). Project Work. New York: Oxford University Press.

Gatehouse, K. (2001). Key issues in English for specific purposes (ESP) curriculum development. The Internet TESL Journal, 7(10), 1-10.

Gülbahar, Y., \& Tinmaz, H. (2006). Implementing project-based learning and e-portfolio assessment in an undergraduate course. Journal of Research on Technology in Education, 38(3), 309-327. https://doi.org/10.1080/15391523.2006.10782462

Hans, A., \& Hans, E. (2015). A Comparative Study of English for Specific Purposes (ESP) and English as a Second Language (ESL) Programs. International Journal on Studies in English Language and Literature, $3(11), 26-31$.

Hedge. (2000). Teaching and Learning in the Language Classroom: A guide to current ideas about the theory and practice of English language teaching. OUP Oxford.

Helle, L., Tynjälä, P., \& Olkinuora, E. (2006). Project-based learning in post-secondary education - theory, practice and rubber slingshots. Higher Education, 51(2), 287-314. https://doi.org/10.1007/s10734-004-6386-5

Huthchinson, T., \& Water, A. (1996). English for Specific Purposes: A learning-centered approach. Great Britain: Bell \& Bain Glasgow.

Ibbotson, M. (2008). Cambridge English for engineering. Student's book: Cambridge University Press.

Jarvis, H. (2004). Investigating the classroom applications of computers on EFL courses at higher education institutions in the UK. Journal of English for Academic Purposes, 3(2), 111-137. https://doi.org/10.1016/j.jeap.2003.08.002

Kavaliauskiene, G. (2004). Research into the integration of content-based instruction into the ESP classroom. Journal of Language and Learning, 2(1), 1-12.

Kavlu, A. (2015). Project-Based Learning Assessment Methods Comparison in Undergraduate EFL Classes. International Journal of Social Sciences \& Educational Studies, 47.

Kavlu, A. (2016). Enhancement of English as a Foreign Language (EFL) University Students' Reading Skills through Project-Based Learning Implementation (Iraqi Case). Doctoral Dissertation in Education Sciences, INTERNATIONAL BLACK SEA UNIVERSITY, Tbilisi, Georgia.

Ke, L. (2010). Project-based college English: An approach to teaching non-English majors. Chinese Journal of Applied Linguistics, 33(4).

Kirkpatrick, A., \& Sussex, R. (2012). English as an International Language in Asia: Implications for Language Education. Springer. https://doi.org/10.1007/978-94-007-4578-0

Klein, J. I., Taveras, S., Hope King, S., Commitante, A., Curtis Bey, L., \& Stripling, B. (2009). Project-based learning: Inspiring middle school students to engage in deep and active learning. New York.

Korpela, J. (2003). English: The Universal Language on the Internet? Electronically Published on the Internet. 
Mamakou, I. (2009). Project-Based Instruction for ESP in Higher Education. In Handbook of Research on E-Learning Methodologies for Language Acquisition (pp. 456-479). IGI Global. https://doi.org/10.4018/978-1-59904-994-6.ch028

Mascolo, M. F. (2009). Beyond student-centered and teacher-centered pedagogy: Teaching and learning as guided participation. Pedagogy and the Human Sciences, 1(1), 3-27.

McKay, S. L. (2002). Teaching English As an International Language: Rethinking Goals and Perspectives. New York: Oxford University Press.

Meyer, D. K., Turner, J. C., \& Spencer, C. A. (1997). Challenge in a mathematics classroom: Students' motivation and strategies in project-based learning. The Elementary School Journal, 501-521. https://doi.org/10.1086/461878

Nassir, S. M. S. (2014). The Effectiveness of Project-based Learning Strategy on Ninth Graders' Achievement Level and their Attitude towards English in Governmental Schools-North Governorate. The Islamic University of Gaza, Deanery of Graduate Studies, Faculty of Education Curriculum \& Instruction Department.

Ngan, N. T. C. (2011). Content-based instruction in the teaching of English for accounting at the Vietnamese college of finance and customs. English Language Teaching, 4(3), 90. https://doi.org/10.5539/elt.v4n3p90

Pennycook, A. (2017). The Cultural Politics of English as an International Language. Taylor \& Francis. https://doi.org/10.4324/9781315225593

Rehm, G., \& Uszkoreit, H. (2012). The English Language in the Digital Age. Springer Berlin Heidelberg. https://doi.org/10.1007/978-3-642-30684-6

Reigeluth, M. (1999, March 10). Principles for learning meaningful knowledge. Retrieved August 09, 2016, from http://www.indiana.edu/ idtheory/methods/m6c.html

Rousová, V. (2008). Project-based Learning. Halloween Party.

Sadeghi, H., Biniaz, M., \& Soleimani, H. (2016). The Impact of Project-Based Language Learning on Iranian EFL Learners Comparison/Contrast Paragraph Writing Skills. International Journal of Asian Social Science, 6(9), 510-524. https://doi.org/10.18488/journal.1/2016.6.9/1.9.510.524

Sheppard, K., \& Stoller, F. L. (1995). Guidelines for the integration of student projects into ESP classrooms. Paper presented at the English Teaching Forum.

Sidman-Taveau. (2005). Computer-assisted project-based learning in the second language: case studies in adult ESL.

Sidman-Taveau, \& Milner-Bolotin, M. (2001). Constructivist Inspiration: A Project-Based Model for L2 Learning in Virtual Worlds. Texas Papers in Foreign Language Education, 6(1), 63-82.

Simpson, J. (2011). Integrating project-based learning in an English language tourism classroom in a Thai university. Ph.D. Thesis, Australian Catholic University.

Sofi-Karim, M. (2015). English Language Teaching in the Kurdistan Region of Iraq. Master, Webster University.

Stoller, F. L. (1997). Project Work: A Means to Promote Language Content. Paper presented at the Forum.

Sylvester, A. (2007). An investigation of project-based learning and computer simulations to promote conceptual understanding in eighth-grade mathematics. Kansas State University.

Tyagi, S., \& Kannan, R. (2013). Implementing Project-Based Learning in Teaching English to Engineering Students. English for Specific Purposes World, 40(14), 1-15.

Welsh, J. A. (2006). An exploration of project-based learning in two California charter schools. ProQuest.

Yalcin, S. A., Turgut, U., \& Buyukkasap, E. (2009). The effect of project-based learning on science undergraduates' learning of electricity, attitude towards physics and scientific process skills. International Online Journal of Educational Sciences, 1(1), 81-105.

Yam, S., \& Rossini, P. (2010). Implementing a project-based learning approach in an introductory property course. PRRES.

Zazulak, S. (2015). English: the language of the internet. Retrieved from https://www.english.com/blog/english-language-internet 


\section{Copyrights}

Copyright for this article is retained by the author, with first publication rights granted to the journal.

This is an open-access article distributed under the terms and conditions of the Creative Commons Attribution license (http://creativecommons.org/licenses/by/4.0/). 